\title{
Evidence That Prostacyclin Modulates the Vascular Actions of Calcium in Man
}

\author{
J. L. Nadier, M. McKay, V. Campese, J. Vrbanac, and R. Horton \\ Section of Endocrinology and Medicine, Los Angeles County/University of Southern California Medical Center, Los Angeles, California \\ 90033; and Department of Pharmacology, University of South Carolina Medical Center, Charleston, South Carolina 29425
}

\begin{abstract}
Increases in extracellular calcium $\left(\mathrm{Ca}^{++}\right)$can alter vascular tone, and thus may result in increased blood pressure $(\mathrm{Bp})$ and reduced renal blood flow (RBF). $\mathrm{Ca}^{++}$can stimulate prostaglandin $\mathbf{E}_{2}$ $\left(\mathrm{PGE}_{2}\right)$ and/or prostacyclin $\left(\mathrm{PGI}_{2}\right)$ release in vitro, which may modulate $\mathrm{Ca}^{++}$vascular effects. However, in man, the effect of $\mathrm{Ca}^{++}$on PG release is not known. To study this, 14 volunteers received low-dose ( $2 \mathrm{mg} / \mathrm{kg} \mathrm{Ca}^{++}$gluconate) or high-dose $(8 \mathrm{mg} /$ kg) $\mathrm{Ca}^{++}$infusions. The low-dose $\mathrm{Ca}^{++}$infusion did not alter systemic or renal hemodynamics, but selectively stimulated $\mathbf{P G I}_{\mathbf{2}}$, as reflected by the stable metabolite 6-keto- $\mathrm{PGF}_{1} \alpha$ in urine $(159 \pm 21-244 \pm 30 \mathrm{ng} / \mathrm{g}$ creatinine, $P<0.02)$. The same $\mathrm{Ca}^{++}$ infusion given during cyclooxygenase blockade with indomethacin or ibuprofen was not associated with a rise in $\mathbf{P G I _ { 2 }}$ and produced a rise in $\mathrm{Bp}$ and fall in RBF. However, sulindac, reported to be a weaker renal PG inhibitor, did not prevent the $\mathrm{Ca}^{++}$-induced $\mathrm{PGI}_{2}$ stimulation $(129 \pm 33-283 \pm 90, P<0.02)$, and $\mathrm{RBF}$ was maintained despite similar increases in $\mathrm{Bp}$. The high-dose $\mathrm{Ca}^{++}$ infusion produced an increase in mean $B p$ without a change in cardiac output, and stimulated urinary 6-keto-PGF $\alpha$ to values greater than that produced by the $2-\mathrm{mg} / \mathrm{kg} \mathrm{Ca}^{++}$dose $(330 \pm 45$ vs. $244 \pm 30, P<0.05)$. In contrast, urinary $P E_{2}$ levels did not change. $\mathrm{A} \mathrm{Ca}^{++}$blocker, nifedipine, alone had no effect on $\mathrm{Bp}$ or urinary 6-keto-PGF, $\alpha$ levels, but completely prevented the $\mathrm{Ca}^{++}$-induced rise in $\mathrm{Bp}$ and 6-keto-PGF $\alpha$ excretion (158 \pm 30 vs. 182 $\pm 38, P>0.2)$. However, the rise in 6-keto-PGF $\alpha$ was not altered by the $\alpha_{1}$ antagonist prazosin (159 $\pm 21-258 \pm 23, P$ $<0.02$ ), suggesting that calcium entry and not $\alpha_{1}$ receptor activation mediates $\mathrm{Ca}^{++}$pressor and $\mathbf{P G I}_{2}$ stimulatory effects. These data indicate a new vascular regulatory system in which $\mathbf{P G I}_{2}$ modulates the systemic and renal vascular actions of calcium in man.
\end{abstract}

\section{Introduction}

Acute and chronic hypercalcemia may increase blood pressure (Bp), ${ }^{1}$ and pharmacological blockade of calcium entry into vas-

This work was presented in part at the National American Federation of Clinical Research Meetings, Washington, DC, 1984, and was published in abstract form (1984. Clin. Res. 32:534).

Address reprint requests to Dr. Nadler, LAC/USC Medical Center, 2025 Zonal Ave., Unit 1, 18-632, Los Angeles, CA 90033.

Received for publication 24 June 1985.

1. Abbreviations used in this paper: AVP, arginine vasopressin; Bp, blood pressure; $\mathrm{CO}$, cardiac output; GC, gas chromatography; HR, heart rate; MAP, mean arterial pressure; PAH, para-aminohippurate; PG, prostaglandin(s); $\mathbf{P G B}_{2}, \mathrm{PGD}_{2}, \mathrm{PGE}_{1}, \mathbf{P G F}_{1} \alpha$, and $\mathrm{PGF}_{2}$, prostaglandins $\mathrm{B}_{2}$, $D_{2}, E_{1}, E_{2}, F_{1} \alpha$, and $F_{2} ; P_{2}$, prostacyclin; $R B F$, renal blood flow.

J. Clin. Invest.

(c) The American Society for Clinical Investigation, Inc. 0021-9738/86/04/1278/07 \$1.00

Volume 77, April 1986, 1278-1284 cular smooth muscle can improve many forms of hypertension (1-4). Transcellular calcium flux also functions as the common in vivo pathway for vasoconstriction induced by arginine vasopressin (AVP), angiotensin II, and norepinephrine (5). Studies in man and experimental animals indicate that a rise in extracellular calcium increases renal vascular resistance, reduces renal blood flow (RBF), and impairs renal function (6-8). Although there is evidence suggesting that calcium can directly produce smooth muscle constriction (9), other studies indicate a more complex interaction with the renin-angiotensin system, catecholamines, and prostaglandins (PG) (10-12).

It has been suggested that vasodilatory $\mathrm{PG}, \mathrm{PGE}_{2}$, and prostacyclin $\left(\mathrm{PGI}_{2}\right)$ may be protective modulators of systemic and RBF. This is supported by experiments showing decrements in renal function after cyclooxygenase inhibition during states of ischaemia, hypovolemia, and sodium depletion (13-15).

Calcium can directly activate membrane phospholipases to release arachidonic acid from membrane phospholipids, which then can be converted into products including $\mathrm{PGE}_{2}$ and/or $\mathrm{PGI}_{2}$. This is supported by in vitro data suggesting that the ionophore A23187, in the presence of calcium, stimulates $\mathrm{PGE}_{2}$ synthesis in the renal medulla and $\mathrm{PGI}_{2}$ production in endothelial cells $(16,17)$. However, the interaction of calcium and PG in man has not been previously investigated.

The present study was designed to investigate $(a)$ the effect of mild and moderate hypercalcemia on vasodilatory PG release; (b) whether $\mathrm{PGE}_{2}$ and/or $\mathrm{PGI}_{2}$ function as negative modulators of calcium's vasocontrictive actions; $(c)$ the role of transcellular calcium flux for the hemodynamic and PG changes induced by calcium; and $(d)$ since previous studies in man indicate that $\alpha_{1}$ adrenergic activation is a potent stimulus for $\mathrm{PGE}_{2}$ and $\mathrm{PGI}_{2}$ release (18), the effect of $\alpha_{1}$ blockade on the hemodynamic and PG effects of calcium. Our study suggests that $\mathrm{PGI}_{2}$ is a modulator of the vascular effects of calcium.

\section{Methods}

Subjects. 14 healthy volunteers were studied at the LAC/USC Clinical Research Center after $5 \mathrm{~d}$ equilibration on a 80 -meq $\mathrm{Na}^{+}, 60$-meq $\mathrm{K}^{+}$ diet. All patients gave informed consent and the protocol was approved by our Internal Review Board. Their ages ranged from 20 to 46 . Eight men and six women were studied. All protocols were performed in the afternoon while the subjects were supine to minimize the effects of posture and diurnal variation (19).

Effect of calcium infusion on systemic and renal hemodynamics. To assess the effect of calcium on the systemic and renal circulation, lowand high-dose calcium infusions were administered over $3 \mathrm{~h}$ via constant intravenous infusion (IMED Pump; IMED Corp., San Diego, CA) at 2 $\mathrm{mg} / \mathrm{kg}(n=14)$, and $8 \mathrm{mg} / \mathrm{kg}$ calcium gluconate $(n=8)$. Bp and pulse rate were measured before and every 30 min during infusion using an automated Bp monitoring system (Dinamap Critikon, Inc., Dublin, CA). Cardiac output $(\mathrm{CO})$ was determined noninvasively via a doppler computer technique (20) during some of the low- and high-dose calcium infusions. This doppler method has been validated via comparison with standard thermodilution methods. RBF was measured using para-aminohippurate (PAH) clearance normalized to $1.73 \mathrm{~m}^{2}$ body surface area. 
PAH was given at a loading dose of $4 \mathrm{mg} / \mathrm{kg}$ and then maintained at a constant infusion. Four baseline plasma samples for PAH were obtained at 5-min intervals after a 2-h equilibration period. Plasma was subsequently obtained at 30-min intervals during the calcium infusions. PAH was measured via a standard spectrophotometric method (21). RBF was calculated as: (effective renal plasma flow)/1 - hematocrit). Serum was obtained for total and ionized calcium before and at hourly intervals during infusions (22).

Effect of $P G$ inhibition on systemic and renal hemodynamics. To evaluate the role of vasodilatory PG in the control of systemic and renal vascular tone during mild and moderate hypercalcemia, cyclooxygenase inhibitors, indomethacin $(50 \mathrm{mg}$ ) (Indocin; Merck Sharpe \& Dohme, West Point, PA) or ibuprofen (600 mg) (Motrin; Upjohn Co., Kalamazoo, MI) were administered orally every $8 \mathrm{~h}$ for $2 \mathrm{~d}$ before the low-dose calcium infusions $(n=14)$. Another cyclooxygenase inhibitor, sulindac $(200 \mathrm{mg})$ (Clinoril; Merck Sharp \& Dohme), was also given orally twice a day for $3 \mathrm{~d}$ to some subjects $(n=7)$ before the low-dose calcium infusions.

Effect of calcium infusions on urinary $P G$ excretion. To assess basal urinary PG levels, 3-h urines (1300-1600 h) were collected on two separate days during intake of $150 \mathrm{ml}$ of water orally or dextrose in water intravenous infusions. The dose effect of calcium on urinary PG excretion was assessed by collecting 3-h urines during both low- $(n=14)$ and high $(n=8)$-dose calcium infusions. Urine was collected in glass bottles, the volume measured, and aliquots were immediately frozen at $-30^{\circ} \mathrm{C}$ for $\mathrm{PGE}_{2}$ and 6-keto-PGF $1 \alpha$ assay. Urine samples were also analyzed for sodium, potassium, and creatinine by standard methods.

Effect of calcium channel blockade on calcium-induced $B p$ and $P G$ changes. Nifedipine (Procardia; Pfizer Inc., New York, NY), a slow calcium channel antagonist (23), was given at a dosage of $20 \mathrm{mg}$ sublingually $30 \mathrm{~min}$ before the high-dose calcium infusion $(n=8)$. The contents of two standard $10-\mathrm{mg}$ nifedipine capsules were punctured and contents placed sublingually. 3-h urines were collected during calcium blockade alone and, on separate days, with the combination of the calcium antagonist and high calcium infusion.

Role of alpha adrenergic activation in calcium-induced hemodynamic and $P G$ changes. Evidence from our lab suggests that catecholamines via $\alpha_{1}$ activation stimulate renal $\mathrm{PGE}_{2}$ and $\mathrm{PGI}_{2}$ in man (18); therefore, the effect of $\alpha_{1}$ adrenergic blockade on calcium-induced hemodynamic and PG alterations was evaluated. The selective $\alpha_{1}$ adrenergic antagonist prazosin ( $5 \mathrm{mg}$ ) (24) (Minipress; Pfizer Inc.) was given orally $1 \mathrm{~h}$ before the high calcium infusions $(n=6)$. This dosage was previously shown to completely block the pressor and $\mathrm{PGI}_{2}$ stimulatory effects of norepinephrine infusion (18). Systemic Bp and pulse rate were determined before prazosin administration and at 30-min intervals thereafter until completion of calcium infusion.

Radioimmunoassay $(R I A)$ of $P G E_{2}$ and 6-keto-PGF $\alpha$ in urine. $\mathrm{PGE}_{2}$ was measured by a previously described method (25) using specific antisera raised in our lab, ethyl acetate extraction, and LH-20 Sephadex chromatography. Antibody cross-reactivity is $\mathrm{PGE}_{2}, 100 \%, \mathrm{PGD}_{2}, 4 \%$, $\mathrm{PGF}_{1} \alpha, 1 \%$, and 6-keto-PGF $\alpha, \mathrm{PGB}_{2}, 13,14-$ dihydro $\mathrm{PGE}_{2}$, and 13,14dihydro- 15 -keto- $\mathrm{PGE}_{2}$, all $<0.1 \%$. Tracer recovery averages $65 \%$, interassay variation $10 \%$, and water blanks carried through the entire method average $3 \mathrm{pg}$. The sensitivity is $10 \mathrm{pg} /$ sample and $50 \%$ displacement occurs at $30 \mathrm{pg}$. RIA validation procedures included assay of serially diluted urine $(r=0.94)$ and comparison with results using the $\mathrm{PGE}_{2}$ antisera from the Institute Pasteur, Paris, France. Comparison revealed a correlation $(r=0.98)$ with slope of $0.93(25)$.

6-keto-PGF $\alpha$ was also measured via our published RIA (26). Urine samples after authentic $\left[{ }^{3} \mathrm{H}\right] 6-\mathrm{keto}-\mathrm{PGF}_{1} \alpha$ is added (New England Nuclear, Boston, MA) are brought to $\mathrm{pH} 3.5$ with $1 \mathrm{~N} \mathrm{HCl}$, and extracted with ethyl acetate. The dried extract is chromatographed on Sephadex LH-20 columns $(0.5 \times 80 \mathrm{~cm})$ using the solvent system dichloromethane/ methanol (95:5). This system completely separates the 2,3-dinor 6-keto$\mathrm{PGF}_{1} \alpha$ metabolite. Antisera was generated in our lab in rabbits by injection of 6-keto-PGF $1 \alpha$ linked to bovine thyroglobulin using the carbiodiimide reaction in a manner described previously for $\mathrm{PGE}_{2}(25)$. The antibody has a working titer of $10^{3}$ dilution with $60-70 \%$ bound at Bo (zero standard added) and $50 \%$ displacement at $50 \mathrm{pg}$. Nonspecific binding is $<5 \%$. Crossreactivity is: 6-keto- $\mathrm{PGF}_{1} \alpha, 100 \%, 2,3$-dinor 6keto-PGF $1 \alpha, 25 \%, \mathrm{PGF}_{2}, 2 \%$, and $\mathrm{PGE}_{2}, \mathrm{PGE}_{1}, \mathrm{PGD}_{2}, 13$,14-dihydro 6,15-diketo $\mathrm{PGF}_{1} \alpha, 13,14$-dihydro-15-keto 2,3-dinor-6-keto-PGF ${ }_{1} \alpha$, all $<0.1 \%$. Recovery of added indicator averages $65 \%$. The bound from free PG is separated using a second antibody technique. The method blank carried through the entire method is $\mathbf{4} \pm 2$ (SD) $\mathrm{pg}$. Intraassay variation is $5 \%$ and interassay variability is $12 \%$. Hourly excretion values are similar to other values reported in the literature. Standard validation procedures have been performed including assay of serially diluted urine $(r=0.98)$ and addition of known amounts of cold standard to urine $(r=0.98)$. Values are unaltered by further chromatography (thin-layer chromatography or reverse-phase high performance liquid chromatography). Further validation was recently completed in collaboration with Dr. J. Vrbanac at the Mass Spectrometry Clinical Research Resource (CLINSPEC) Laboratory at the Department of Pharmacology, Medical University of South Carolina. Two gas chromatography mass spectrometric methods were used. Initially, we utilized a $t$-butyl dimethyl silyl ether derivative of 6keto-PGF $\alpha$ (27) using a Hewlett-Packard HP5970A Mass Selective Dector. A 30-m DB-5 bonded phase-fused silica capillary column (J \& W Scientific, $0.25 \mathrm{~mm}$ i.d., $0.25 \mu \mathrm{m}$ film thickness) was interfaced directly with the ion source. Conditions of analysis were: electron impact at 70 $\mathrm{eV}$; injection port temperature of $290^{\circ} \mathrm{C}$; splitless injection; $\mathrm{U}=35 \mathrm{~cm} /$ $\mathrm{s}$; injection port surge after $3 \mathrm{~min}$; column temperature during injection of $200^{\circ} \mathrm{C}$; initial rapid ramp to $270^{\circ} \mathrm{C}$, then programming at $3^{\circ} \mathrm{C} / \mathrm{min}$ to $310^{\circ} \mathrm{C}$. The $\mathrm{M}^{+}-57$ ion was used for quantitation $(698.5$ protium, 702.5 deuterium). Deuterated 6-keto- $\mathrm{PGF}_{1} \alpha$, used as internal standard, was kindly provided by Dr. John Pike (Upjohn Co.). Two gas chromatography (GC) peaks representing the syn- and antistereoismers for the methyl ester-methoxine $t$-butyl dimethyl ether derivative of 6-keto-PGF ${ }_{1} \alpha$ eluted between 14.6 and $14.9 \mathrm{~min}$.

For increased sensitivity, a negative ion chemical ionization procedure was utilized using a Finnigan $3200 \mathrm{GC} /$ mass spectrometer modified for negative ion capabilities (28). The methoxine-pentafluorobenzyl-trimethyl silyl derivative of 6-keto-PGF $\alpha$ was prepared using the method of Blair (29). For GC a 30-min DB-I bonded phase-fused silica capillary column was directly interfaced with the ion source. Conditions of analysis were as follows: negative ion chemical ionization using methane as the reagent gas; $80 \mathrm{eV}$; on-column injection at $190^{\circ} \mathrm{C}$; and temperature programming from $270^{\circ}$ to $300^{\circ} \mathrm{C}$ at $4^{\circ} \mathrm{C} / \mathrm{min}$. Fragment ions at $618.5\left({ }^{2} \mathrm{H}_{4}\right)$ and 614.5 $\left({ }^{1} \mathrm{H}\right)$ were monitored $\left[\mathrm{M}-\mathrm{C}_{7} \mathrm{H}_{2} \mathrm{~F}_{5}\right]$.

The RIA gave a good correlation with the GC/mass spectrometric values obtained $(r=0.80)$.

Statistical analysis. All data was analyzed using a CLINFO computer. Paired student's $t$ test was used to compare results. Each subject was used as his or her own control. All results are reported as the mean \pm SE. All urinary PG values are expressed in units of nanograms per gram of creatinine.

\section{Results}

Effects of low-dose calcium infusion on systemic and renal hemodynamics. The effect of the $2-\mathrm{mg} / \mathrm{kg}$ dose calcium infusion on systemic and renal hemodynamics is shown on Table $\mathrm{I}$. This dose of calcium did not alter Bp, heart rate (HR), CO, or RBF. Mild hypercalcemia was produced with this dosage and ionized calcium concentration increased slightly $(5.00 \pm 0.06-5.44 \pm 0.10$ $\mathrm{mg} / \mathrm{dl}, P<0.02$ ), while total serum calcium levels remained unchanged. The infusion did not produce changes in urinary potassium, creatinine, or volume (Table II). However, urinary sodium excretion increased (10.4 $\pm 3.4-21.9 \pm 7.8 \mathrm{meq} / \mathrm{liter}, P$ $<0.05)$.

In marked contrast to the lack of hemodynamic effects of this calcium infusion, the same dose of calcium during cyclooxygenase inhibition produced a significant increase in systemic and renal vascular tone (Fig. 1). The calcium infusion with in- 
Table I. Effect of Low-dose Calcium Infusion on Systemic and Renal Hemodynamics

\begin{tabular}{lllllllll}
\hline & $\mathrm{T} \mathrm{Ca}$ & $\mathrm{I} \mathrm{Ca}$ & Systolic Bp & Diastolic Bp & MAP & CO & HR & $\begin{array}{l}\text { RBF } \\
\left(\mathrm{ml} / \mathrm{min}^{\prime} / .73 \mathrm{~m} \mathrm{~m}^{2}\right)\end{array}$ \\
\hline $\begin{array}{llll}\text { Control } \\
\begin{array}{l}\text { Calcium } \\
\text { infusion }\end{array}\end{array}$ & $9.1 \pm 0.2$ & $5.00 \pm 0.06$ & $117 \pm 5$ & $76 \pm 4$ & $85 \pm 2$ & $6.5 \pm 0.4$ & $68 \pm 4$ & $1,210 \pm 100$ \\
& $9.3 \pm 0.2$ & $5.44 \pm 0.10^{*}$ & $115 \pm 5$ & $77 \pm 2$ & $86 \pm 2$ & $6.9 \pm 0.6$ & $66 \pm 3$ & $1,180 \pm 80$ \\
\hline
\end{tabular}

T Ca, total serum calcium; I Ca, ionized calcium. $* P<0.02$.

domethacin or ibuprofen produced a significant increase in mean arterial pressure (MAP) $(14 \pm 3 \mathrm{mmHg}, P<0.01)$ and a $28 \%$ fall in RBF $\left(1,210 \pm 100-860 \pm 60 \mathrm{ml} / \mathrm{min}\right.$ per $\left.1.73 \mathrm{~m}^{2}, P<0.01\right)$ (Fig. 1). Similarly, another cyclooxygenase inhibitor, sulindac, produced an increase in MAP during the low-dose calcium infusion (Fig. 1). However, sulindac pretreatment did not alter $\operatorname{RBF}(1,160 \pm 42$ vs. $1,180 \pm 80, P>0.3)$. Cyclooxygenase inhibitors given alone did not alter basal MAP or RBF $(84 \pm 3 \mathrm{mmHg}$ and $1,190 \pm 70 \mathrm{ml} / \mathrm{min}$ per $1.73 \mathrm{~m}^{2}$, respectively, both $P>0.3$ ).

Effect of the low-dose calcium on $P G$ release. The effect of the low-dose calcium infusion on vasodilatory PG excretion is shown in Fig. 2. The 2-mg/ $/ \mathrm{kg}$ calcium dose significantly increased urinary 6-keto-PGF $\alpha$ release $(159 \pm 21-244 \pm 30 \mathrm{ng} / \mathrm{g}$ creatinine, $P<0.02$ ). In contrast, urinary $\mathrm{PGE}_{2}$ excretion decreased. Indomethacin administration completely prevented the calciuminduced rise in 6-keto- $\mathrm{PGF}_{1} \alpha$ excretion and resulted in levels below the control $(102 \pm 18 \mathrm{ng} / \mathrm{g}$ creatinine). However, sulindac did not alter basal 6-keto-PGFi $\alpha(130 \pm 33$ vs. $159 \pm 21, P>0.3)$ or the calcium-induced stimulation of $\mathrm{PGI}_{2}(129 \pm 33-283 \pm 90$, $P<0.02$ ), Fig. 3 .

Effect of high-dose calcium infusion on $B p$ and vasodilatory $P G$ release. The $8-\mathrm{mg} / \mathrm{kg}$ calcium infusion increased MAP $(87 \pm 3-108 \pm 4 \mathrm{mmHg}, P<0.01)$ and total serum calcium

Table II. Effect of Calcium Infusions Alone or with Antagonists on Urinary $\mathrm{Na}^{+}, \mathrm{K}^{+}$, Creatinine, and Volume

\begin{tabular}{lllll}
\hline Infusion & $\begin{array}{l}\mathrm{Na} \\
(\mathrm{meq} / 3 \mathrm{~h})\end{array}$ & $\begin{array}{l}\mathrm{K}^{+} \\
(\mathrm{meq} / 3 \mathrm{~h})\end{array}$ & $\begin{array}{l}\text { Creatinine } \\
(\mathrm{mg} / 3 \mathrm{~h})\end{array}$ & $\begin{array}{l}\text { Volume } \\
(\mathrm{mg} / 3 \mathrm{~h})\end{array}$ \\
\hline $\begin{array}{l}\text { Control }(n=14) \\
\text { Low dose } \mathrm{Ca}^{2+} \\
(n=14)\end{array}$ & $10.4 \pm 3.4$ & $17.2 \pm 2.8$ & $293 \pm 31$ & $402 \pm 111$ \\
$\begin{array}{c}\text { Low dose } \mathrm{Ca}^{2+} \\
+ \text { indomethacin } \\
(n=14)\end{array}$ & $21.9 \pm 7.8^{*}$ & $16.3 \pm 1.7$ & $269 \pm 26$ & $425 \pm 114$ \\
$\begin{array}{c}\text { High dose } \mathrm{Ca}^{2+} \\
(n=8)\end{array}$ & $16.4 \pm 6.1$ & $13.5 \pm 4.6$ & $243 \pm 39$ & $596 \pm 198$ \\
$\begin{array}{c}\text { High dose } \mathrm{Ca}^{2+} \\
+ \text { nifedipine } \\
(n=8)\end{array}$ & $45.7 \pm 11.3 \ddagger$ & $17.8 \pm 3.4$ & $299 \pm 39$ & $652 \pm 104^{*}$ \\
$\begin{array}{c}\text { High dose } \mathrm{Ca}^{2+} \\
+ \text { prazosin } \\
(n=6)\end{array}$ & $21.5 \pm 5.1 \S$ & $13.6 \pm 2.8$ & $263 \pm 33$ & $522 \pm 176$ \\
& $20.7 \pm 14.3 \S$ & $13.6 \pm 1.0$ & $393 \pm 120$ & $599 \pm 185$
\end{tabular}

$* P<0.05$ vs. control.

$\ddagger P<0.01$ vs. control.

$\S P<0.05$ vs. high $\mathrm{Ca}^{2+}$.
(9.2 $\pm 0.1-12.4 \pm 0.4 \mathrm{mg} / \mathrm{dl}, P<0.001)$. However, $\mathrm{CO}$ was not altered (6.9 \pm 0.6 vs. $6.5 \pm 0.4 \mathrm{liter} / \mathrm{min}, P>0.3)$, suggesting MAP rose due to increases in peripheral vascular resistance. Urinary $\mathrm{K}^{+}$and creatinine did not change, but $\mathrm{Na}^{+}$excretion and volume increased (Table II).

Fig. 4 shows the effects of the high-dose calcium infusion on urinary PG excretion. $\mathrm{PGE}_{2}$ levels were not altered by the calcium infusion. In contrast, urinary 6-keto-PGF $1 \alpha$ excretion was markedly stimulated and levels were greater than that produced by the low calcium infusion $(330 \pm 45$ vs. $244 \pm 30 \mathrm{ng} / \mathrm{g}$ creatinine, $P<0.05$ ), suggesting a dose-response effect. The subsequent studies were designed to investigate the mechanism of this calcium-induced stimulation of $\mathbf{P G I}_{2}$.

Effect of calcium channel inhibition and alpha adrenergic blockade on calcium-mediated $\mathrm{PGI}_{2}$ release. Nifedipine completely prevented the rise in MAP produced by the high calcium infusion ( $87 \pm 2$ vs. $82 \pm 2 \mathrm{mmHg}, P=\mathrm{NS})$. The high-dose calcium infusion increased urinary $\mathrm{Na}^{+}$and volume, but these changes were significantly blocked by nifedipine (Table II). No changes in urinary $\mathrm{K}^{+}$or creatinine were observed during these maneuvers. The calcium blocker prevented the calcium-induced rise in 6-keto-PGF $\alpha$ and produced levels not significantly different than control ( $170 \pm 24$ vs. $210 \pm 46 \mathrm{ng} / \mathrm{g}$ creatinine) (Fig. 5). Nifedipine given alone on a separate day to five subjects did not alter basal MAP $(82 \pm 4 \mathrm{mmHg})$ or 6 -keto- $\mathrm{PGF}_{1} \alpha$ excretion ( $158 \pm 30$ vs. $182 \pm 38)$.

Prazosin given before the calcium infusion resulted in urinary $\mathrm{Na}^{+}, \mathrm{K}^{+}$, creatinine, and volume that were similar to levels obtained during calcium channel blockade with nifedipine (Table

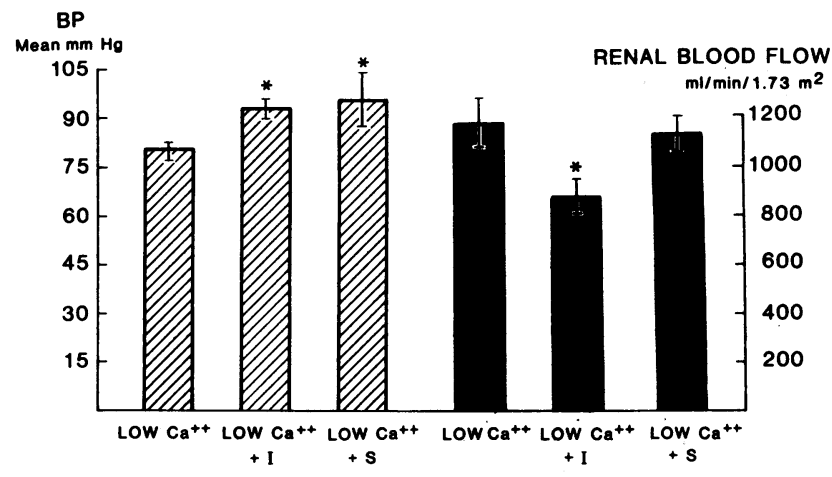

Figure 1. Effect of low dose calcium administration alone or with cyclooxygenase inhibitors on mean Bp $(\varpi)$ and $\operatorname{RBF}(\square)$. Bars represent mean \pm SEM. Low Ca alone $(n=14)$. I, indomethacin $(n=8)$ and ibuprofen $(n=6)$. S, sulindac $(n=7) .{ }^{*} P<0.01\left(\right.$ low $\mathrm{Ca}^{++}+$inhibitor vs. low $\mathrm{Ca}^{++}$alone). 


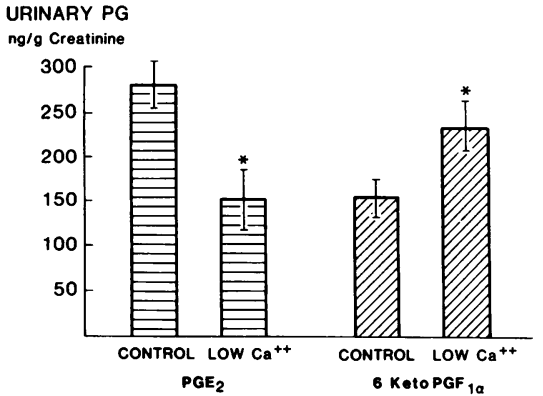

Figure 2. Effect of low dose calcium infusion on urinary $\mathrm{PGE}_{2}$ (国) and 6-keto-PGF $\alpha(\square)$ excretion. Mean \pm SEM values are shown. $n=14, P$ $<0.02$ (low $\mathrm{Ca}^{++}$vs. control).

II). However, prazosin did not prevent the pressor effect of the calcium infusion (88 $\pm 3-102 \pm 4 \mathrm{mmHg}, P<0.02$ ), and did not alter the high calcium-induced rise in 6-keto-PGF $\alpha(159 \pm 21-$ $258 \pm 23, P<0.02$ ) (Fig. 5).

\section{Discussion}

Considerable evidence suggests that vasodilatory PG play a key role as protective modulators of systemic and RBF during states of increased pressor activity (30-33). Studies in animals and man indicate that angiotensin II and norepinephrine stimulate $\mathrm{PGE}_{2}$ and/or $\mathrm{PGI}_{2}$ release $(18,26,34-36)$, while cyclooxygenase blockade produces decrements in renal function during states of ischemia, heart failure, or sodium depletion $(14,15,37,38)$. Inhibition of renal PG synthesis results in unopposed renal vasoconstriction, which reduces blood flow and glomerular filtration rate.

Many reports suggest that an increase in extracellular calcium can alter systemic and renal vascular tone, thus increasing Bp and reducing $\operatorname{RBF}(1-4,6-8,10)$. The mechanisms of calciuminduced vascular effects are complex, since calcium can directly produce vascular smooth muscle constriction (9) or mediate the pressor actions of AVP and angiotensin II $(5,39)$. Other studies suggest a major role for catecholamines since calcium can stimulate norepinephrine release and mediate $\alpha_{1}$ adrenergic receptor activity $(4,40-42)$.

The present results indicate that $\mathbf{P G I}_{2}$ is a potent modulator of the systemic and renal vascular actions of calcium. The lowdose calcium infusion given alone did not alter systemic or renal vascular hemodynamics. In contrast, the same calcium infusion given during indomethacin or ibuprofen administration pro-

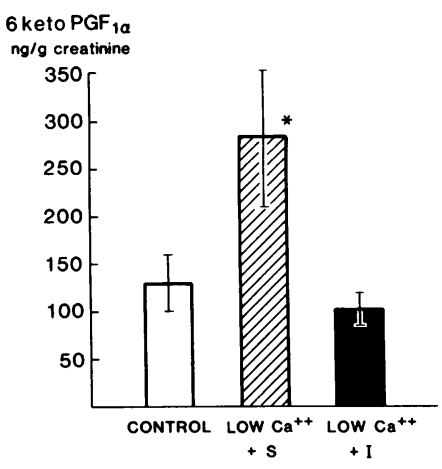

Figure 3. Effect of sulindac (S) and indomethacin (I) on calcium-stimulated 6-keto$\mathrm{PGF}_{1} \alpha$ release. Bars represent mean \pm SEM values. $n$ $=7$ for $\mathrm{S}$, and $n=18$ for $\mathrm{I}$. ${ }^{*} P<0.01$ (low $\mathrm{Ca}^{++}+\mathrm{S}$ vs. control).

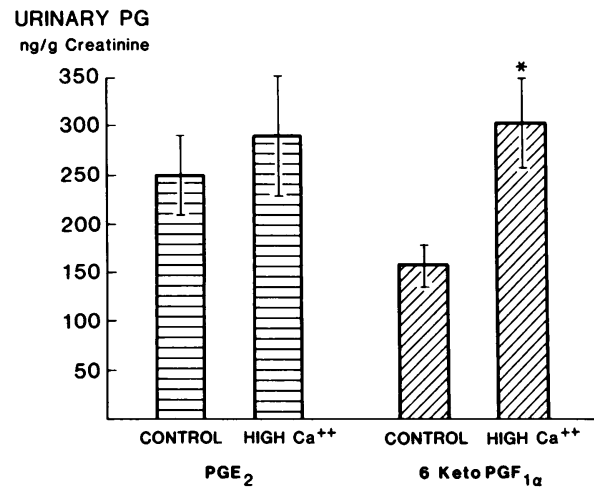

Figure 4. Effect of high dose calcium infusion on urinary $\mathrm{PGE}_{2}$ (目) and 6-keto-PGF ${ }_{1} \alpha(\square)$ excretion. $n=8,{ }^{*} P<0.01$ (high $\mathrm{Ca}^{++}$vs. control).

duced a significant increase in Bp and reduction in RBF. Both cyclooxygenase inhibitors totally prevented the calcium induced rise in 6-keto-PGF ${ }_{1} \alpha$, suggesting that $\mathrm{PGI}_{2}$ attenuates the vasoconstrictive effects of calcium.

Sulindac has been reported to differ from other cyclooxygenase inhibitors by sparing renal, but inhibiting systemic PG, as reflected by a lack of effect on urinary 6-keto-PGF ${ }_{1} \alpha$ and $\mathrm{PGE}_{2}$ excretion, while lowering systemic $\mathrm{PG}$, as reflected by reduced platelet thromboxane formation $(43,44)$. However, a recent study in healthy men showed that although basal $\mathrm{PGE}_{2}$ or 6-keto-PGF $\mathrm{P}_{1} \alpha$ were not altered, furosemide-stimulated $\mathrm{PGE}_{2}$, but not 6-keto-PGF ${ }_{1} \alpha$ release, was reduced by sulindac (45). In addition, other evidence in dogs indicates that the active sulfide form of sulindac when delivered in high concentrations into the renal artery inhibits renal PG production (46). Therefore, sulindac may partially spare renal PG synthesis due to the reduced levels of active drug that reach the site of renal PG synthesis.

In our study, the results obtained with sulindac were different than with indomethacin or ibuprofen. The infusion of calcium with sulindac did not change RBF despite similar rises in systemic Bp obtained with the other cyclooxygenase inhibitors. In addition, sulindac did not alter either basal or calcium-stimulated levels of urinary 6-keto-PGF ${ }_{1} \alpha$. These results suggest that sulindac may partially spare renal $\mathrm{PGI}_{2}$ production, and that urinary 6-keto-PGF ${ }_{1} \alpha$ primarily reflects renal $\mathrm{PGI}_{2}$ synthesis, a conclusion that is consistent with reports by others $(47,48)$.

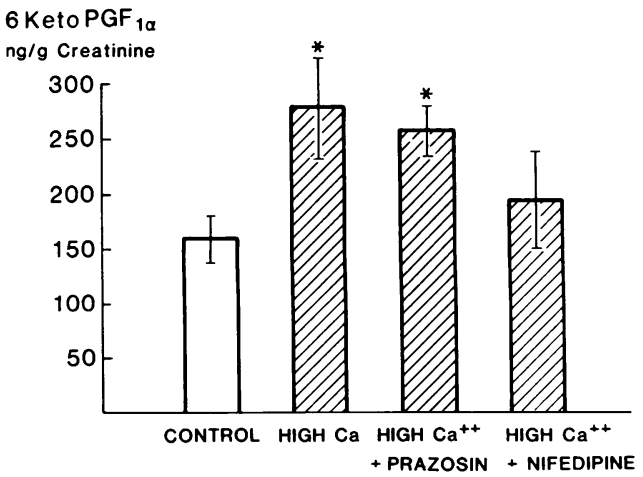

Figure 5. Effect of prazosin and nifedipine on high dose calcium-stimulated 6-keto- $\mathrm{PGF}_{1} \alpha$ release. $n=8$ for high $\mathrm{Ca}$ alone and high $\mathrm{Ca}$ + nifedipine. $n=6$ for prazosin. ${ }^{*} P<0.01$. 
The low-dose calcium infusion produced no rise in total calcium and only minimal increases in ionized calcium concentration. However, even this slight calcium increase stimulated $\mathrm{PGI}_{2}$ synthesis, as reflected by an increase in 6-keto-PGF ${ }_{1} \alpha$ excretion. This suggests that $\mathrm{PGI}_{2}$ production is very sensitive to even small changes in extracellular calcium concentration.

Previous evidence in vitro suggests that calcium plays a key role in PG biosynthesis. The divalent cation ionophore A23187 in the presence of calcium stimulates $\mathrm{PGE}_{2}$ synthesis in renal medullary tissue (16). More recent evidence indicates that the mechanism of calcium-induced $\mathrm{PGE}_{2}$ synthesis is via phospholipase $\mathrm{A}_{2}$ activation through a calmodulin-dependent mechanism $(49,50)$. A23187 in the presence of calcium also stimulates $\mathrm{PGI}_{2}$ synthesis in endothelial cells and vascular smooth muscle in culture $(17,51,52)$.

The source of the calcium needed for vasodilatory PG biosynthesis is not known. However, recent evidence indicates that $\mathrm{PGI}_{2}$ and $\mathrm{PGE}_{2}$ may respond to different cellular pools of calcium. Extracellular calcium is particularly important for $\mathrm{PGI}_{2}$ production in vascular tissue. Increases in extracellular calcium directly stimulates $\mathbf{P G I}_{2}$ synthesis in endothelial cells through a mechanism involving calcium entry (53). The resulting increase in intracellular calcium activates phospholipase $A_{2}$ via calmodulin. In contrast, other evidence suggests a key role for intracellular calcium for $\mathrm{PGE}_{2}$ release in renal tissue. The ionophore A23187-mediated $\mathrm{PGE}_{2}$ release is via an increase in intracellular calcium, since changes in extracellular calcium concentration alone do not alter $\mathrm{PGE}_{2}$ release in renal medullary tissue (16, 54). In cultured medullary collecting tubules, basal $\mathrm{PGE}_{2}$ synthesis requires the presence of extracellular calcium, but increasing extracellular calcium from 1.0 to $4.0 \mathrm{mM}$ does not further alter $\mathrm{PGE}_{2}$ release $(54,55)$. Therefore, changes in extracellular calcium in vivo may selectively alter renal $\mathrm{PGI}_{2}$ synthesis.

The higher dose calcium infusion produced marked hypercalcemia and a clear pressor response. The mechanism of the Bp increase was through a change in peripheral vascular resistance, since $\mathrm{CO}$ did not increase. Some studies suggest that calcium can stimulate catecholamine release, which can then produce pressor effects through $\alpha_{1}$ receptor activation $(40,42)$. To evaluate this potential interaction, the selective $\alpha_{1}$ antagonist prazosin was administered before some high-dose calcium infusions. The results of these studies suggest that the pressor action of increased extracellular calcium is not secondary to catecholamine release and $\alpha_{1}$ adrenergic activation, since prazosin did not alter the pressor response. In contrast, nifedipine completely prevented the calcium-induced Bp increase, suggesting that direct calcium entry is a major mechanism of altered vasomotor tone.

In comparison with the low dose of calcium, the higher dose infusion produced a greater rise in urinary 6-keto- $\mathrm{PGF}_{1} \alpha$ excretion. These results suggest that the calcium stimulation of $\mathrm{PGI}_{2}$ release is dose related.

In addition to its pressor actions, norepinephrine stimulates $\mathrm{PGI}_{2}$ synthesis in vitro and in man via $\alpha_{1}$ adrenergic receptor activation $(18,36)$. We therefore evaluated the effect of prazosin on the calcium-induced urinary 6-keto-PGF $\alpha$ increase. Prazosin did not alter the calcium stimulated of $\mathrm{PGI}_{2}$ excretion, suggesting that this response was not via $\alpha_{1}$ receptor activation. The dosage of prazosin used was previously shown to completely prevent norepinephrine-induced pressor and $\mathrm{PGI}_{2}$ stimulatory effects (18). Therefore, if the calcium effect was secondary to catecholamine release, it would have been blocked by prazosin.
Nifedipine given alone did not alter urinary 6-keto-PGF $1 \alpha$ excretion. However, the calcium antagonist markedly blunted the calcium-induced $\mathrm{PGI}_{2}$ release. These results indicate that increasing extracellular calcium concentration stimulates $\mathbf{P G I}_{2}$ release through a mechanism involving calcium entry that is sensitive to calcium antagonists. This is the first evidence in man indicating the critical role of extracellular calcium and its entry for $\mathrm{PGI}_{2}$ synthesis.

The low and higher dose calcium infusions failed to stimulate urinary $\mathrm{PGE}_{2}$ excretion despite marked increases in 6-keto$\mathrm{PGF}_{1} \alpha$. The precise explanation for this selective action of extracellular calcium to stimulate only $\mathrm{PGI}_{2}$ is not totally clear from this study. One explanation is that $\mathrm{PGE}_{2}$ synthesis may be less sensitive to acute changes in extracellular calcium $(54,55)$. In addition, recent evidence in vitro suggests that $\mathrm{PGE}_{2}$ synthesis produced by hormones such as angiotensin II is linked to specific pools of hormonally sensitive calcium that activate phospholipase $A_{2}$ (56). Other reports in the isolated rat kidney indicate that omission of calcium or addition of calcium blockers to the perfusion medium, which attenuate the effect of AVP to produce renal vasoconstriction, fail to alter the increase in renal PG elicited by the peptide (57). This evidence suggests that AVP-induced renal PG synthesis does not require extracellular calcium. Therefore, the selectivity in renal PG synthesis can be due to different local cellular responses, depending upon the pool of calcium involved in phospholipase $A_{2}$ activation and PG synthesis. Alternatively, the phospholipases may reside at different subcellular sites, making them more or less responsive to hormonal and/or calcium effects. The present results suggest that the arachidonic acid released in response to changes in extracellular calcium is primarily converted into $\mathrm{PGI}_{2}$, resulting in unaltered or reduced levels of $\mathrm{PGE}_{2}$.

The measurement of another $\mathrm{PGI}_{2}$ metabolite in urine, 2,3 dinor 6-keto-PGF $\alpha$ has been reported to represent an index of systemic vascular $\mathrm{PGI}_{2}$ production (58). Although an additional study measuring the dinor metabolite could further test our contention that $\mathrm{Ca}^{++}$stimulates both renal and extrarenal $\mathrm{PGI}_{2}$, we were unable to use this technique in the current investigation. Since urinary 6-keto- $\mathrm{PGF}_{1} \alpha$ primarily reflects renal $\mathrm{PGI}_{2}$ production, our conclusion that $\mathrm{Ca}^{++}$stimulates renal and extrarenal $\mathrm{PGI}_{2}$ synthesis is based upon indirect evidence. We have reviewed the extensive literature showing in vitro that $\mathrm{Ca}^{++}$alters systemic vascular tone and $\mathrm{PGI}_{2}$ synthesis. In addition, the current results reveal marked changes in systemic and renal hemodynamics during the low-dose $\mathrm{Ca}^{++}$infusion, with general PG inhibition and only systemic changes with the more selective extrarenal cyclooxygenase inhibitors.

In summary, this study indicates a new vascular regulatory system in which $\mathrm{PGI}_{2}$ plays a key role in modulating the systemic and renal vascular actions of calcium. $\mathrm{PGI}_{2}$ synthesis is highly sensitive to changes in extracellular calcium and variations in calcium entry that provide support for its physiologic role in man.

\section{Acknowledgments}

The authors wish to express their appreciation to Ms. J. Yamamoto for her technical aid and Ms. S. Bitolas for her excellent secretarial assistance.

This work was supported in part by National Institutes of Health grants RR-43 and HL21112. Dr. Nadler is the recipient of (NIH) Clinical Investigator Award HLO 1496. 


\section{References}

1. Earll, J. M., N. A. Kurtzman, and R. H. Moser. 1966. Hypercalcemia and hypertension. Ann. Intern. Med. 64:378-381.

2. Aoki, K., S. Kondo, A. Mochizuki, T. Yoshida, S. Kato, K. Kato, and K. Takikawa. 1978. Antihypertensive effect of cardiovascular $\mathrm{Ca}^{2+}$ antagonist in hypertensive patients in the absence and presence of betaadrenergic blockade. Am. Heart J. 96:218-226.

3. Pedersen, O. L. 1983. Calcium blockade in arterial hypertension. Hypertension. 5(Suppl. II):74-79.

4. Marone, C., C. Beretta-Piccoli, and P. Weidman. 1980. Acute hypercalcemic hypertension in man: role of hemodynamics, catecholamines and renin. Kidney Int. 20:92-96.

5. Goldberg, J. P., and R. W. Schrier. 1984. Effect of calcium membrane blockers on in vivo vasoconstrictor properties of norepinephrine, angiotensin II, and vasopressin. Miner. Electrolyte Metab. 10:178-183.

6. Chomdej, B., P. D. Bell, and L. G. Navar. 1977. Renal hemodynamic and autoregulatory responses to acute hypercalcemia. Am. J. Physiol. 232:F490-F496.

7. Gill, J. R., Jr., and F. C. Bartter. 1961. On the impairment of renal concentrating ability in prolonged hypercalcemia and hypercalciuria in man. J. Clin. Invest. 40:716-722.

8. Humes, H. D., I. Ichikawa, J. L. Troy, and B. M. Brenner. 1978. Evidence for a parathyroid hormone-dependent influence of calcium on the glomerular ultrafiltration coefficient. J. Clin. Invest. 61:32-40.

9. Bohr, D. F. 1973. Vascular smooth muscle updated. Circ. Res. 32:665-672.

10. Levi, M., M. A. Ellis, and T. Berl. 1983. Control of renal hemodynamics and glomerular filtration rate in chronic hypercalcemia: role of prostaglandins, renin-angiotensin system, and calcium. J. Clin. Invest. 71:1624-1632.

11. Bianchetti, M. G., C. Beretta-Piccoli, P. Weidman, L. Link, K. Boehringer, C. Ferrier, and J. L. Morton. 1983. Calcium and blood pressure regulation in normal and hypertensive subjects. Hypertension. 5(Suppl. II):57-65.

12. Vlachakis, N. D., R. Frederics, M. Velasquez, N. Alexander, F. Singer, and R. F. Maronde. 1982. Sympathetic system function and vascular reactivity in hypercalcemic patients. Hypertension. 4:452-458.

13. Dunham, E., and B. Zimmerman. 1970. Release of prostaglandinlike material from dog kidney during nerve stimulation. Am. J. Physiol. 219:1279-1285.

14. Terragno, N., A. Terragno, and J. McGiff. 1977. Contributions of prostaglandins to the renal circulation in conscious, anesthetized and laparotimized dogs. Circ. Res. 40:590-595.

15. Zipser, R., J. Hoefs, P. Speckart, P. Zia, and R. Horton. 1979. Prostaglandins: modulators of renal function and pressor resistance in chronic liver disease. J. Clin. Endocrinol. Metab. 48:895-900.

16. Knapp, H. R., O. Oelz, L. J. Roberts, B. J. Sweetman, J. A. Oates, and P. W. Reed. 1977. Ionophores stimulate prostaglandin and thromboxane biosynthesis. Proc. Natl. Acad. Sci. USA. 74:4251-4255.

17. Brotherton, A. F., and J. C. Hoak. 1982. Role of $\mathrm{Ca}^{2+}$ and cyclic AMP in the regulation of the production of prostacyclin by the vascular endothelium. Proc. Natl. Acad. Sci. USA. 79:495-499.

18. Nadler, J., R. Zipser, and R. Horton. 1983. The effect of adrenergic stimulation on urinary prostaglandin $\mathrm{E}_{2}$ and 6 keto $\mathrm{PGF}_{1} \alpha$ in man. Prostaglandins. 26:519-530.

19. Nadler, J. L. 1986. Diurnal variation and exercise induced changes of prostacyclin in man. Prostaglandins, Leukotrienes, and Medicine. In press.

20. Chandraratna, T., M. Nanna, C. McKay, A. Nimalasuriya, R. Swinney, U. Elkayam, and S. Rahimtoola. 1984. Determination of cardiac output by transcutaneous continuous wave ultrasonic doppler computer. Am. J. Cardiol. 53:234-237.

21. Harvey, R., and A. Brothers. 1962. Renal extraction of paraaminohippurate and creatinine measured by continuous in vivo sampling of arterial and renal vein blood. NY Acad. Sci. 102:46-54.

22. Brauman, J., C. H. Delivingne, and H. Brauman. 1981. Mea- surement of blood ionized calcium vs. total calcium in normal man in renal insufficiency and in hypercalcemia of various origins. Scand. $J$. Clin. Lab. Invest. 43(Suppl. 165):75-59.

23. Motulsky, H., M. Snavely, R. Hughes, and P. Insel. 1983. Interaction of verapamil and other calcium channel blockers with $\alpha_{1}$ and $\alpha_{2}$ adrenergic receptors. Circ. Res. 52:226-231.

24. Hoffman, B., C. DeLean, C. Wood, D. Schocken, and R. J. Lefkowitz. 1979. Alpha-adrenergic receptor subtypes: quantitative assessment by ligand binding. Life Sci. 24:1739-1746.

25. Zia, P., R. Zipser, P. Speckart, and R. Horton. 1978. The measurement of urinary prostaglandin $\mathrm{E}$ in normal subjects and in high renin states. J. Lab. Clin. Med. 92:415-422.

26. Nadler, J., R. Zipser, R. Coleman, and R. Horton. 1983. Stimulation of renal prostaglandins by pressor hormones in man: comparison of $\mathrm{PGE}_{2}$ and $\mathrm{PGI}_{2}$. J. Clin. Endocrinol. Metab. 56:1260-1266.

27. Bazan, A., and D. Knapp. 1982. Improved derivative of 6 keto $\mathrm{PGF}_{1} \alpha$ for gas chromatography-mass spectrometic analysis. J. Chromatogr. 236:201-207.

28. Bruins, A. P. 1983. A simple and inexpensive modification of a Finnigan 3200 quadrupole mass spectrometer for negative ion detection. Biomed. Mass Spectrom. 10:46-49.

29. Blair, I., S. Barrow, K. Waddell, P. Lewis, and C. T. Dollery. 1982. Prostacyclin is not a circulating hormone in man. Prostaglandins. 23:579-589.

30. McGiff, J., K. Crowshaw, N. Terragno, and A. Lonigro. 1970. Renal prostaglandins, possible regulators of the renal actions of pressor hormones. Nature (Lond.). 227:1255-1257.

31. Aiken, J., and J. Vane. 1973. Intrarenal prostaglandin release attenuates the renal vasoconstrictor activity of angiotensin. J. Pharmacol. Exp. Ther. 184:678-687.

32. Lonigro, A., H. Itskowitz, K. Crowshaw, and J. McGiff. 1973. Dependence of renal blood flow on prostaglandin synthesis in the dog. Circ. Res. 32:712-717.

33. Negus, P., R. Tannen, and M. Dunn. 1976. Indomethacin potentiates the vasoconstrictor actions of angiotensin II in normal man. Prostaglandins. 12:175-180.

34. Schlondorff, D., S. Rocyniak, J. Satriano, and V. Folkert. 1980. Prostaglandin synthesis by isolated rat glomeruli: effect of angiotensin II. Am. J. Physiol. 239:F486-F495.

35. Needleman, P., J. Douglas, Jr., B. Jakshik, P. Stoecklein, and E. Johnson, Jr. 1974. Release of renal prostaglandins by catecholamines: relationship to renal endocrine function. J. Pharmacol. Exp. Ther. 188: 453-460.

36. Levine, L., and M. Moskowitz. 1979. $\alpha$ and $\beta$ adrenergic stimulation of arachidonic acid metabolism in cells in culture. Proc. Natl. Acad. Sci. USA. 76:6632-6636.

37. Dzau, V., M. Packer, L. Lilly, S. Swartz, N. Hollenberg, and G. Williams. 1984. Prostaglandins in severe congestive heart failure: relation to activation of the renin-angiotensin system and hyponatremia. $N$. Engl. J. Med. 310:347-352.

38. Clive, D., and J. S. Stoff. 1984. Renal syndromes associated with nonsteroidal anti-inflammatory drugs. $N$. Engl. J. Med. 310:563-572.

39. Deth, R., and C. VanBreeman. 1974. Relative contributions of $\mathrm{Ca}^{2+}$ influx and cellular calcium release during drug induced activation of the rabbit aorta. Pfluegers Arch. Eur. J. Physiol. 348:13-22.

40. Burn, J., and W. Gibson. 1965. The release of noradrenalin from sympathetic nerve fibers in relation to calcium concentration. J. Physiol. 181:214-223.

41. Exton, J. 1980. Mechanisms involved in alpha-adrenergic phenomena: role of calcium ions in the actions of catecholamines in liver and other tissues. Am. J. Physiol. 238:E3-E12.

42. Steele, T., and L. Challoner-Hue. 1984. Renal interactions between norepinephrine and calcium antagonists. Kidney Int. 26:719-724.

43. Ciabattoni, G., G. Cinotti, A. Pierucci, B. Simonetti, M. Manzi, F. Pugliese, P. Barsotti, G. Pecci, F. Taggi, and C. Patrono. 1984. Effects of sulindac and ibuprofen in patients with chronic glomerular disease. N. Engl. J. Med. 310:279-283. 
44. Miller, M., F. Bednar, and J. McGiff. 1983. Renal metabolism of sulindac, a novel nonsteroidal anti-inflammatory agent. In Advances in Prostaglandin Thromboxane Research. B. Samuelsson, R. Paoletti, and P. Ramwell, editors. Raven Press, New York. 11:487-491.

45. Brater, D., S. Anderson, B. Baird, and W. Campbell. 1985. Effects of ibupropen, naproxen, and sulindac on prostaglandins in men. Kidney Int. 27:66-73.

46. Zambraski, E., A. Chremos, and M. Dunn. 1984. Comparison of the effects of sulindac with other cyclooxygenase inhibitors on prostaglandin excretion and renal function in normal and chronic bile ductligated dogs and swine. J. Pharmacol. Exp. Ther. 228:560-566.

47. Patrono, C., F. Pugliese, G. Ciabattoni, A. Patrignani, A. Masen, S. Chlerchia, B. Peskar, G. Cinotti, B. Simonetti, and A. Pierucci. 1982. Evidence for a direct stimulatory effect of prostacyclin on renin release in man. J. Clin. Invest. 69:231-239.

48. Fitzgerald, G., A. Pedersen, and C. Patrono. 1983. Analysis of prostacyclin and thromboxane biosynthesis in cardiovascular disease. Circulation. 67:1174-1177.

49. Craven, P., and F. DeRubertis. $\mathrm{Ca}^{2+}$-calcium dependent release of arachidonic acid for renal medullary prostaglandin synthesis: evidence for involvement of phospholipases $\mathrm{A}_{2}$ and $\mathrm{C}_{2}$. J. Biol. Chem. 258:48144823.

50. Craven, P., R. Studer, and F. DeRubertis. 1981. Renal inner medullary prostaglandin synthesis: a calcium-calmodulin dependent process suppressed by urea. J. Clin. Invest. 68:722-732.

51. Dejana, E., G. Balconi, C. De Castellarnau, B. Barbieri, M. Ver-
gara-Douden, and G. De Gaetano. 1983. Prostacyclin production by human endothelial and bovine smooth muscle cells in culture: effect of repeated stimulation with arachidonic acid, thrombin, and ionophore A23 187. Biochim. Biophys. Acta. 750:261-267.

52. Weksler, B., C. Ley, and E. Jaffe. 1978. Stimulation of endothelial cell prostacyclin production by thrombin, trypsin and the ionophore A23 187. J. Clin. Invest. 62:923-930.

53. Whorton, A., C. Willis, R. Kent, and S. Young. 1984. The role of calcium in the regulation of prostacyclin synthesis by porcine aortic endothelial cells. Lipids. 19:17-24.

54. Zenser, T., C. Herman, and B. Davis. 1980. Effects of calcium and $\mathrm{A} 23187$ on renal inner medullary prostaglandin $\mathrm{E}_{2}$ synthesis. $\mathrm{Am}$. J. Physiol. 238:E371-376.

55. Teitelbaum, I., A. Wolf, and T. Berl. 1984. Control of prostaglandin synthesis in cultured rat inner medullary collecting tubule cells: the role of calcium. IX Int. Cong. Nephrol., Los Angeles (Abstr.).

56. Scharschmidt, L., and M. Dunn. 1983. Prostaglandin synthesis by rat glomerular mesangial cells in culture: effects of angiotensin II and arginine vasopressin. J. Clin. Invest. 71:1756-1764.

57. Cooper, C., and K. Malik. 1984. Mechanism of action of vasopressin on prostaglandin synthesis and vascular function in the isolated rat kidney: effect of calcium antagonists and calmodulin inhibitors. $J$. Pharmacol. Exp. Ther. 229:139-147.

58. Fitzgerald, G., A. Brash, P. Falardeau, and J. Oates. 1981. Estimated rate of prostacyclin secretion into the circulation of normal man. J. Clin. Invest. 68:1272-1276. 